Article

\title{
Suppressive Effect of Bioactive Extracts of Bacillus sp. H8-1 and Bacillus sp. K203 on Tomato Wilt Caused by Clavibacter michiganensis subsp. michiganensis
}

\author{
Hwajin Jang ${ }^{1,2}$, Sang Tae Kim ${ }^{1,2}$ and Mee Kyung Sang ${ }^{1, *}$ \\ 1 Division of Agricultural Microbiology, National Institute of Agricultural Sciences, Rural Development \\ Administration, Wanju 55365, Korea; hjjang@gmail.com (H.J.); stkim9312@gmail.com (S.T.K.) \\ 2 Department of Applied Bioscience, Dong-A University, Busan 49315, Korea \\ * Correspondence: mksang@korea.kr; Tel.: +82-63-238-3055; Fax: +82-63-238-3834
}

Citation: Jang, H.; Kim, S.T.; Sang, M.K. Suppressive Effect of Bioactive Extracts of Bacillus sp. H8-1 and Bacillus sp. K203 on Tomato Wilt Caused by Clavibacter michiganensis subsp. michiganensis. Microorganisms 2022, 10, 403. https://doi.org/ 10.3390/microorganisms10020403

Academic Editor: Dawn L. Arnold

Received: 28 December 2021

Accepted: 7 February 2022

Published: 9 February 2022

Publisher's Note: MDPI stays neutral with regard to jurisdictional claims in published maps and institutional affiliations.

Copyright: (C) 2022 by the authors. Licensee MDPI, Basel, Switzerland. This article is an open access article distributed under the terms and conditions of the Creative Commons Attribution (CC BY) license (https:// creativecommons.org/licenses/by/ $4.0 /)$.

\begin{abstract}
Tomatoes are cultivated worldwide, and are economically important. Clavibacter michiganensis subsp. michiganensis $(\mathrm{Cmm})$ is a pathogen that causes canker and wilting in tomatoes, resulting in serious damage to tomato plants. We aimed to control $\mathrm{Cmm}$ proliferation using substances produced by useful microorganisms. The water extracts of strains H8-1 and K203 inhibited wilting caused by $\mathrm{Cmm}$ and slowed the pathogenic colonization in tomato plants. The relative expressions of $c e l A$, celB, pat1, and pelA of Cmm treated with the bacterial water extracts were reduced by $0.41-, 0.01-$, $0.15-$, and 0.14-fold for H8-1, respectively, and 0.45-, 0.02-, 0.13-, and 0.13-fold for K203, respectively, compared to controls at $72 \mathrm{~h}$ after treatments. In tomato plants inoculated with $\mathrm{Cmm}$, when water extracts of H8-1 and K203 were treated, relative expression of ACO encoding 1-aminocyclopropane-1carboxylic acid oxidase was suppressed by 0.26- and 0.23-fold, respectively, while PR1a was increased by 1.94- and 2.94-fold, respectively; PI2 expression was increased by 3.27-fold in water extract of H81-treated plants. As antioxidant enzymes of plants inoculated with $\mathrm{Cmm}$, peroxidase and glutathione peroxidase levels were increased in K203-water-extract-treated plants, and catalase was increased in the case of the H8-1 water extract at 10 days after inoculation. In terms of soil enzyme activity, each water extract tended to increase urease activity and microbial diversity; in addition, K203 water extract increased plant growth. Thus, H8-1 and K203 water extracts can be used as potential biocontrol agents against $\mathrm{Cmm}$.
\end{abstract}

Keywords: Bacillus spp. biocontrol; bioactive extract; Clavibacter michiganensis subsp. michiganensis

\section{Introduction}

Tomatoes are the second most important crop in the world, with a total output of 182 million tons [1,2]. Clavibacter michiganensis subsp. michiganensis (Cmm) is a soil-borne bacterial pathogen that reduces tomato yield and quality, resulting in significant economic losses [3-6]. Most soil pathogens are Gram-negative, whereas Cmm is a Gram-positive bacterium belonging to Actinomyces that causes significant crop losses by causing wilt and canker disease in tomato plants [7-10]. Cmm systemically infects host plants through wounds, pores, and seeds, causing wilt and canker symptoms [7]. When Cmm infects the early stages of host plants, they develop systemic infections, referred to as primary infections, which affect the quality and harvest of fruits, and generally cause death. If $\mathrm{Cmm}$ infects older plants, they usually develop foliage infections referred to as secondary infections, which cause chlorosis of leaves, but may or may not affect the quality and yield of current crops [11]. During infection, colonization, and disease progression, Cmm secretes cell-wall-degrading enzymes such as cellulase, xylanase, and pectate degradation enzymes, which participate in the decomposition of plant cell wall components such as cellulose, xylan, and pectin, respectively, to promote $\mathrm{Cmm}$ colonization and nutrient acquisition [12]. 
About $16 \%$ of differentially expressed genes at 8 days post-inoculation are involved in defense during $\mathrm{Cmm}$ infection; defense-related genes result in the production and elimination of free oxygen radicals, enhancement of protein turnover, and hormone (including ethylene) synthesis and reaction [13]. Moreover, in order to combat pathogen infections, host plants activate basic defense responses through pathogenesis-related (PR) proteins when recognizing extracellular pathogen-related molecular patterns (PAMPs) [14,15]. In general, these PR proteins have antibacterial properties, and are involved in cellular activities such as defensive signaling, cell wall hydrolysis, production of active oxygen species, contact toxicity, and alkalization of the medium [16,17]. It is also well known that the plant hormones jasmonic acid (JA), salicylic acid (SA), abscisic acid (ABA), and ethylene (ET) act as dominant primary signals in the regulation of plants' local and systemic defense responses [18]. In general, pathogen-induced systemic acquired resistance (SAR) depends on the SA-regulated signaling pathway [19], and induced systemic resistance (ISR) by beneficial microorganisms generally relies on JA signaling [20-22].

Despite this defense, many plants are infected, and several approaches for disease management have been developed; for instance, various chemical pesticides are used for disease control [23]. Despite the clear positive contributions to the efficient control of plant fungal diseases and pests, there is a lack of effective pesticides for controlling bacterial pathogens in rapidly developed infection [24]. In addition, concerns are growing over the side effects of chemical pesticide abuse in terms of soil and water pollution, as well as toxicity to beneficial organisms [25,26]. Accordingly, the increase in the demand for pesticide substitutes provides opportunities for the expansion of biological control $[27,28]$. Amkraz et al. [29] reported biological control agents with antagonism against $\mathrm{Cmm}$ using fluorescent pseudomonades under greenhouse conditions. In addition, a study by AboElyousr et al. [30] found that Bacillus subtilis, B. amyloliquefaciens, Pseudomonas fluorescens, and P. aeruginosa reduced the disease severity caused by $\mathrm{Cmm}$, and it was confirmed that the four bacteria produced bioactive metabolites such as siderophores, $\mathrm{HCN}$, and indole acetic acid, which could be applied as eco-friendly alternatives in the future.

Our study aimed to find effective bacteria-derived extracts as eco-friendly alternatives for controlling $\mathrm{Cmm}$ in vitro and in planta. We also investigated the mode of action of the bacterial extracts from various perspectives including $\mathrm{Cmm}$ colonization and pathogenicityrelated gene expression, plant antioxidant response and gene expression, and soil activities, by studying total microbial activity, phosphatase and urease activities, and diversity, based on the use of 31 carbon sources. The results of this study allowed us to understand the effects of bacterial bioactive extracts on the control of $\mathrm{Cmm}$ in broad contexts of $\mathrm{Cmm}$ infection stages, host plant response, and soil microbial environments.

\section{Materials and Methods}

\subsection{Bacterial Strains}

In total, 95 epiphytic strains were isolated from the leaves, stems, flowers, and rhizospheres of various plants (tomatoes, cucumber cabbages, turmeric, chives, and strawberries) in various regions (Miryang, Kimje, Gangneung, and Jeju). Samples (1 g) were added to $9 \mathrm{~mL}$ of sterile $10 \mathrm{mM} \mathrm{MgSO}_{4}$ solution, incubated for $30 \mathrm{~min}$ at $160 \mathrm{rpm}$ and $28^{\circ} \mathrm{C}$, and smeared on tryptic soy agar (TSA, Difco, Sparks, MD, USA) medium containing cycloheximide $(50 \mu \mathrm{g} / \mathrm{mL})$ to prevent fungal growth and obtain only bacteria. After three days of incubation, morphologically distinct colonies were isolated and stored in tryptic soy broth medium (TSB, Difco) supplemented with $20 \%$ glycerol at $-80^{\circ} \mathrm{C}$ before use [31].

\subsection{Cell Viability Test and Cellulase Test}

All of the isolated strains were cultivated on TSA for 3 days at $28{ }^{\circ} \mathrm{C}$, and single colonies were transferred to $5 \mathrm{~mL}$ of TSB. After incubation for 2 days at $160 \mathrm{rpm}$ and $28^{\circ} \mathrm{C}$, bacterial cells were removed by centrifugation at $6000 \mathrm{rpm}$ for $20 \mathrm{~min}$, followed by filtering (0.22 um syringe filter, Techno Plastic Products AG, Product NO 99722, Trasadingen, Switzerland), and the cell-free broth was placed at $4{ }^{\circ} \mathrm{C}$ before use. The bacterial pathogen, 
Clavibacter michiganensis subsp. michiganensis (Cmm, KACC 16995), was grown on nutrient broth yeast extract agar (NBYA) medium ( $8 \mathrm{~g}$ of nutrient broth, $2 \mathrm{~g}$ of yeast extract, $2.5 \mathrm{~g}$ of glucose, $2 \mathrm{~g}$ of $\mathrm{KH}_{2} \mathrm{PO}_{4}, 0.5 \mathrm{~g}$ of $\mathrm{KH}_{2} \mathrm{PO}_{4}, 1.5 \mathrm{~g}$ of $\mathrm{MgSO}_{4} \cdot 7 \mathrm{H}_{2} \mathrm{O}$, and $15 \mathrm{~g}$ of agar per liter) at $28^{\circ} \mathrm{C}$ for 3 days [32], and a single colony was propagated in nutrient broth yeast extract broth (NBY) at $28^{\circ} \mathrm{C}$ and $160 \mathrm{rpm}$ for $24 \mathrm{~h}$. Cmm pellets were obtained by centrifugation at $3500 \mathrm{rpm}$ for $5 \mathrm{~min}$ twice [33], and $\mathrm{Cmm}$ suspension $\left(\mathrm{OD}_{640}=1.0\right)$ was prepared in $10 \mathrm{mM}$ $\mathrm{MgSO}_{4}$ solution. The mixture of a cell-free supernatant and Cmm suspension $(9: 1, v / v)$ was incubated in each well of 96-well plates for $24 \mathrm{~h}$; PrestoBlue Cell Viability Reagent $(10 \%$, $v / v$, Invitrogen, Waltham, MA, USA) was added to the 96-well plates and incubated at $37^{\circ} \mathrm{C}$ for $10 \mathrm{~min}$. Cell viability was measured at a wavelength of $570 \mathrm{~nm}$ using a microplate reader (Infinite M200 Pro, TECAN, Männedorf, Switzerland), and compared with that of a mixture of $\mathrm{Cmm}$ suspension and TSB.

For measurement of the cellulase activity of $\mathrm{Cmm}$, M9 minimal medium $(7 \mathrm{~g}$ of $\mathrm{Na}_{2} \mathrm{HPO}_{4} \cdot 7 \mathrm{H}_{2} \mathrm{O}, 3 \mathrm{~g}$ of $\mathrm{KH}_{2} \mathrm{PO}_{4}, 0.5 \mathrm{~g}$ of $\mathrm{NaCl}, 1 \mathrm{~g} \mathrm{NH} \mathrm{Nl}_{4}, 0.492 \mathrm{~g}$ of $\mathrm{MgSO}_{4} \cdot 7 \mathrm{H}_{2} \mathrm{O}$ $0.111 \mathrm{~g}$ of $\mathrm{CaCl}_{2}$ and $15 \mathrm{~g}$ of agar per liter) containing $0.1 \% \mathrm{w} / v$ of yeast extract and $0.5 \%$ $w / v$ of carboxymethyl cellulose (CMC) was used. The mixture $(10 \mu \mathrm{L})$ of $1 / 10$ diluted cell-free supernatant and $\mathrm{Cmm}$ suspension $(9: 1, v / v)$ was incubated in the center of M9 minimal medium for 3 days at $28^{\circ} \mathrm{C}$, and then stained with Congo red for $2 \mathrm{~h}$. After washing three times with $1 \mathrm{M} \mathrm{NaCl}$, the yellow color was recorded as a positive response [34].

\subsection{Plant Material and Inoculation}

Tomatoes (Solanum lycopersicum, 'Superdotaerang', Koregon, Anseong, Korea) were used for all plant experiments under greenhouse conditions, with a 16/8 h (light/dark) photoperiod at $25 \pm 5{ }^{\circ} \mathrm{C}$ and $50 \pm 5 \%$ relative humidity. Tomato seeds were grown in pots $(10 \mathrm{~cm}$, diameter) containing a potting mixture (Baroker, SeoulBio, Eumseong, Korea). C. michiganensis subsp. michiganensis was cultured as described above. For the inoculation of $\mathrm{Cmm}$ in tomato (five-to-six-leaf stage) plants [23], four-holes (1.5 cm distance to plants, $5 \mathrm{~cm}$ depth) were prepared in all tested plants, including controls, for uniform disease occurrence, and then the mixture $(20 \mathrm{~mL} /$ plant, $1: 1, v / v)$ of $\mathrm{Cmm}$ suspension $\left(10^{9} \mathrm{CFU} / \mathrm{g}\right)$ and tenfolddiluted supernatant was put into the four-holes ( $5 \mathrm{~mL} / \mathrm{hole}$ ). A mixture of $\mathrm{Cmm}$ suspension and tenfold-diluted TSB, and streptomycin ( $250 \mu \mathrm{g} / \mathrm{g}$ of soil) - which acts against $\mathrm{Cmm}$-were used as the negative and positive controls, respectively. For the plant growth promotion test, tomato plants (five-to-six-leaf stage) were used. Water extracts of H8-1 and K203 (1000 $\mu \mathrm{g} / \mathrm{g}$ of soil) were added; three weeks later, the weight of the upper part of the plants was measured. The experiment was conducted in three replicates of eight plants each.

\subsection{Bacterial Identification and Characterization}

To identify the three strains (K203, H8-1, and GLSH03), total genomic DNA was extracted, and 16s rRNA was amplified using primers 785F and 907R, and compared with sequences of type strains using the EzBioCloud database. Phylogenetic trees were constructed using the neighbor-joining method of the Molecular Evolutionary Genetics Analysis (MEGA) program. API 50CH/B and API ZYM (bioMérieux, Marcy-l'Étoile, France) were used for bacterial characterization. Three strains-K203, H8-1, and GLSH03were adjusted to $\mathrm{OD}_{600}=0.45$ for API $50 \mathrm{CH} / \mathrm{B}$ and $\mathrm{OD}_{600}=0.67$ for API ZYM, and the bacterial suspension was added to each strip according to the manufacturer's instructions. API $50 \mathrm{CH} / \mathrm{B}$ and API ZYM were read at $48 \mathrm{~h}$ and $4 \mathrm{~h}$ after incubation at $28^{\circ} \mathrm{C}$, respectively.

\subsection{Preparation of Bacterial Extract and Biocontrol Activity in Tomato Plants}

Three strains-K203, H8-1, and GLSH03-were cultured, and cell-free supernatants were prepared as described above. A cell-free supernatant was sequentially partitioned by solvents, n-hexene, dichloromethane, ethyl acetate, and n-butanol based on polarity. Each mixture of solvent and cell-free supernatant $(1: 1, v / v)$ was shaken at $200 \mathrm{rpm}$ for $12 \mathrm{~h}$, and each organic solvent and water fraction was collected. The collected fractions were evaporated and concentrated. The final solvent and water fractions were dissolved 
in methanol and HPLC-grade water, respectively [35]. The concentrated extracts were stored at $4{ }^{\circ} \mathrm{C}$ after filtering $(0.22 \mu \mathrm{m}$ syringe filter) before use. To evaluate the effect of each extract on $\mathrm{Cmm}$ viability, various concentrations of solvent extracts $(0,1,10,50$, 100,500 , and $1000 \mu \mathrm{g} / \mathrm{mL}$ ) and water extracts $(0,1,10,25,50$, and $100 \mathrm{mg} / \mathrm{mL}$ ) were tested. After determining the bioactive extract via the $\mathrm{Cmm}$ viability assay, a plant test was conducted as mentioned above. The solvent extracts did not suppress $\mathrm{Cmm}$ viability (data not shown). Various concentrations $(1,10,100$, and $1,000 \mu \mathrm{g} / \mathrm{g}$ of soil) of the water extract and $\mathrm{Cmm}$ suspension $\left(10^{9} \mathrm{CFU} / \mathrm{g}\right.$ of soil) were added into four holes ( $5 \mathrm{~cm}$ depth) at a distance of $1.5 \mathrm{~cm}$ from tomato plants, and controls were also treated in the holes. Twenty days after inoculation, disease incidence, severity, and area under the disease progress curve (AUDPC) were evaluated. Disease severity was scored as follows: $0=$ no symptoms; $1=0-25 \%$ leaf wilting; $2=26-50 \%$ leaf wilting; $3=51-75 \%$ leaf wilting; $4=76-100 \%$ leaf wilting; and $5=$ dead [36].

\subsection{Cmm Colonization in Tomato Plants}

As described above, $\mathrm{Cmm}$-inoculated tomato plants (five-to-six-leaf stage) were prepared, and tomato nodes ( 1 to 4 ) from the soil line were sampled at 1, 3, 7, 15, and 20 days after inoculation. Sampled stem segments were homogenized using a mixer mill (Retsch, MM200), followed by smearing serial dilutions on the bacterial canker of the tomato (BCT) medium [37]. Subsequently, the number of CFUs was counted for quantification of the Cmm population in tomato plants. The experiment was conducted twice, with five replicates each.

\subsection{Antioxidant Enzyme Assay}

For the antioxidant enzyme assay, tomato leaves were collected 1, 3, 5, 7, and 10 days after inoculation and homogenized using a mixer mill (Retsch, MM200, Haan, Germany) in liquid $\mathrm{N}_{2}$. For the catalase assay, sampled leaves were homogenized in $250 \mu \mathrm{L}$ of $50 \mathrm{mM}$ potassium phosphate buffer containing $1 \mathrm{mM}$ EDTA, the supernatant was collected after centrifugation at $10,000 \mathrm{rpm}$ for $15 \mathrm{~min}$ at $4{ }^{\circ} \mathrm{C}$, and the activity was determined using a catalase assay kit (Cayman, Item No. 70700, Ann Arbor, MI, USA). For superoxide dismutase activity, the leaves were homogenized in $500 \mu \mathrm{L}$ of $20 \mathrm{mM}$ HEPES buffer containing $1 \mathrm{mM}$ EGTA, $210 \mathrm{mM}$ mannitol, and $70 \mathrm{mM}$ sucrose, and then centrifuged at 10,000 rpm for $15 \mathrm{~min}$ at $4{ }^{\circ} \mathrm{C}$, and superoxide dismutase activity was determined using a superoxide dismutase assay kit (Cayman, Item No. 706002, Ann Arbor, MI, USA). For glutathione peroxidase activity, leaves were homogenized in $1 \mathrm{~mL}$ of homogenization buffer containing $50 \mathrm{mM}$ Tris- $\mathrm{HCl}$ (pH 7.5), $5 \mathrm{mM}$ EDTA, and $10 \mathrm{mM}$ DTT, and then centrifuged at 10,000 rpm for $15 \mathrm{~min}$ at $4{ }^{\circ} \mathrm{C}$; glutathione peroxidase activity was measured using a glutathione peroxidase assay kit (Cayman, Item No. 703102, Ann Arbor, MI, USA). Peroxidase activity was assayed following the manufacturer's instructions (Abcam, ab155895, Cambridge, UK). The total protein content of each sample was determined using the Bradford method [38]. The experiment was conducted twice, with five replicates each.

\subsection{Pathogenicity-Related Gene Expression of Cmm}

$\mathrm{Cmm}$ was incubated in M9 minimal medium (MM) containing $0.4 \% \mathrm{CMC}$ at $28{ }^{\circ} \mathrm{C}$ and sampled at $0,24,48$, and $72 \mathrm{~h}$ after incubation for $\mathrm{Cmm}$ RNA extraction. Bacterial cells were collected by centrifugation at 13,000 rpm for $1 \mathrm{~min}$ at $4{ }^{\circ} \mathrm{C}$, and the pellet was frozen and stored at $-80^{\circ} \mathrm{C}$. Bacterial RNA was extracted using an easy-spin (DNA-free) total RNA extraction kit (Intron Biotechnology Catalog 17221, Seongnam, Korea). RNA quantification was performed using a NanoDrop spectrophotometer (Thermo Fisher Scientific, Waltham, MA, USA). cDNA was synthesized using PrimeScript ${ }^{\mathrm{TM}}$ RT Master Mix (Takara, Catalog \#RR036A, Kusatsu, Japan) for $15 \mathrm{~min}$ at $37^{\circ} \mathrm{C}$ and $15 \mathrm{~s}$ at $85^{\circ} \mathrm{C}$. Specific primers were used for pathogenicity-related gene expression, as described in Table 1 . The $\mathrm{Cmm}$ gene gyrA was used as the reference gene. The real-time qPCR reaction was conducted with $3 \mu \mathrm{L}$ of cDNA, $1 \mu \mathrm{L}$ of 10 pmol of each primer, $10 \mu \mathrm{L}$ of SYBR Green with high ROX (Enzynomics, Catalog RT500S, Daejeon, Korea), and $5 \mu \mathrm{L}$ of RNase-free water, using a qPCR CFX $96^{\mathrm{TM}}$ Real-Time System 
(Bio-Rad, Hercules, CA, USA). The cycling program consisted of an initial denaturation step of $10 \mathrm{~min}$ at $95^{\circ} \mathrm{C}$, followed by 40 cycles at $95^{\circ} \mathrm{C}$ for $5 \mathrm{~s}, 60^{\circ} \mathrm{C}$ for $15 \mathrm{~s}$, and $72{ }^{\circ} \mathrm{C}$ for $20 \mathrm{~s}$ [39]. The experiment was conducted twice, with four replicates each.

Table 1. Primers of pathogenicity-related genes of Clavibacter michiganensis subsp. michiganensis (Cmm).

\begin{tabular}{|c|c|c|c|}
\hline Cmm Genes & Sequence $\left(5^{\prime} \rightarrow 3^{\prime}\right)$ & Expressed Gene & References \\
\hline Gyrase & $\begin{array}{l}\text { Forward: GTGGTCGGCGAGGTC } \\
\text { Reverse: GCGCGAGCGGGTAG }\end{array}$ & gyrA & \\
\hline Cellulase A & $\begin{array}{c}\text { Forward: GGTTCTCCGCATCAAACTATCC } \\
\text { Reverse: TGCTTGTCGCTCGTCGTC }\end{array}$ & celA & \\
\hline Cellulase B & $\begin{array}{l}\text { Forward: GGAGACCACCAGCGACAAG } \\
\text { Reverse: TGAACGACCAGAACGACGAG }\end{array}$ & celB & \\
\hline Serine protease & $\begin{array}{l}\text { Forward: GCTGATTCGCGAGAGGATC } \\
\text { Reverse: GTTCTCGGTTGCTGTGTCGC }\end{array}$ & pat-1 & [39] \\
\hline Chp family protease & $\begin{array}{l}\text { Forward: GACTGCTAATCACTGTGTTG } \\
\text { Reverse: CAATAAACCGTTCCGATGG }\end{array}$ & $\operatorname{chpC}$ & \\
\hline Chymotrypsin-related serine protease & $\begin{array}{l}\text { Forward: AATCGGGCTGGTTCTGGTTT } \\
\text { Reverse: AGATTCTGCGGCATCTGCAT }\end{array}$ & ppaA & \\
\hline Pectinase & $\begin{array}{l}\text { Forward: GTGCGTTCCTGCGGTAAC } \\
\text { Reverse: GCGGATGGTGATGTGGTC }\end{array}$ & pelA1 & \\
\hline
\end{tabular}

\section{9. qRT-PCR for Plant Gene Expression}

Tomato samples (leaves) were collected at $0,24,48$, and $72 \mathrm{~h}$ after inoculation in tomato plants and homogenized using a mixer mill in liquid $\mathrm{N}_{2}$. For qRT-PCR analysis, total RNA was extracted using a plant RNA extraction kit (Intron, Catalog 17491, Seongnam, Korea), and the RNA was quantified using a NanoDrop spectrophotometer. cDNA was synthesized using PrimeScript ${ }^{\mathrm{TM}}$ RT Master Mix for $15 \mathrm{~min}$ at $37^{\circ} \mathrm{C}$ and $15 \mathrm{~s}$ at $85^{\circ} \mathrm{C}$. For plant gene expression, specific primers were used, as described in Table 2. The tomato plant gene GAPDH was used as the reference gene. The real-time qPCR reaction was conducted with $2 \mu \mathrm{L}$ of cDNA, $1 \mathrm{uL}$ of 10 pmol of each primer, $10 \mu \mathrm{L}$ of SYBR Green with high ROX, and $6 \mu \mathrm{L}$ of RNase-free water, using the qPCR CFX $96^{\mathrm{TM}}$ Real-Time System. The program used for qRT-PCR was $10 \mathrm{~min}$ at $95^{\circ} \mathrm{C}$ (initial denaturation), followed by 40 cycles of $15 \mathrm{~s}$ at $95^{\circ} \mathrm{C}, 20 \mathrm{~s}$ at $52{ }^{\circ} \mathrm{C}$, and $20 \mathrm{~s}$ at $72{ }^{\circ} \mathrm{C}[40]$. The experiment was conducted twice with four replicates each.

Table 2. Primers of defense-related genes of tomato.

\begin{tabular}{|c|c|c|c|}
\hline Tomato Plant Genes & Sequence $\left(5^{\prime} \rightarrow 3^{\prime}\right)$ & Expressed Gene & Reference \\
\hline Pathogenesis-related protein & $\begin{array}{l}\text { Forward: GTGGGATCGGATTGATATCCT } \\
\text { Reverse: CCTAAGCCACGATACCATGAA }\end{array}$ & PR1a & \multirow{4}{*}{ [40] } \\
\hline Proteinase inhibitor & $\begin{array}{l}\text { Forward: AATTATCCATCATGGCTGTTCAC } \\
\text { Reverse: CCTTTTTGGATCAGATTCTCCTT }\end{array}$ & PI2 & \\
\hline $\begin{array}{c}\text { 1-Aminocyclopropane-1-carboxylix } \\
\text { acid oxidase }\end{array}$ & $\begin{array}{l}\text { Forward: AAGATGGCACTAGGATGTCAATAG } \\
\text { Reverse: TCCTCTTCTGTCTTCTCAATCAAC }\end{array}$ & $A C O$ & \\
\hline $\begin{array}{l}\text { Glyceraldehyde 3-phosphate } \\
\text { dehydrogenase }\end{array}$ & $\begin{array}{l}\text { Forward: CTGGTGCTGACTTCGTTGTTG } \\
\text { Reverse: GCTCTGGCTTGTATTCATTCTCG }\end{array}$ & GAPDH & \\
\hline
\end{tabular}

\subsection{Soil Microbial Activities and Diversity by EcoPlate}

Soil samples were collected at 5, 10, 15, and 20 days after inoculation of tomato plants. The experiment was conducted twice, with five replicates each. For total microbial activity, fluorescein diacetate hydrolysis (FDase) of soil samples was measured as described by Schnürer and Rosswall [41]. Soils ( $1 \mathrm{~g}$ ) were added to $4 \mathrm{~mL}$ of $60 \mathrm{mM}$ sodium phosphatase buffer ( $\mathrm{pH} 7.6$ ), fluorescein diacetate (FDA, final concentration $10 \mu \mathrm{g} / \mathrm{mL}$ ), and $4 \mathrm{~mL}$ of $60 \mathrm{mM}$ sodium phosphate buffer, and the mixture was incubated at $25^{\circ} \mathrm{C}$ for $1 \mathrm{~h}$. By adding acetone, the reaction was terminated and filtered through a two-layer filter paper (Whatman, No. 2, Maidstone, UK). The filtered solution was then measured at OD $490 \mathrm{~nm}$. 
The soil urease activity was determined according to the method described by Kandeler and Gerber [42]. Soils $(1 \mathrm{~g})$ were added to $0.5 \mathrm{~mL}$ of $0.72 \mathrm{M}$ urea solution and $4 \mathrm{~mL}$ of $0.06 \mathrm{M}$ borate buffer at $\mathrm{pH} 10.0$, and incubated at $37^{\circ} \mathrm{C}$ for $2 \mathrm{~h}$. Finally, $1 \mathrm{~N} \mathrm{KCl}$ was added to $0.01 \mathrm{~N} \mathrm{HCl}$ for termination. After incubation for $30 \mathrm{~min}$, the soil suspension was filtered using a two-layer filter paper (Whatman No. 2, Maidstone, UK). Na salicylate solution $(1 \mathrm{~mL})$ and $0.1 \%$ Na dichloroisocyanurate $(0.4 \mathrm{~mL})$ were added to the filtrate $(1 \mathrm{~mL})$; after incubation for $30 \mathrm{~min}$, the enzyme activity was determined at $690 \mathrm{~nm}$.

Soil acid phosphatase activity was determined using the method described by Tabatabai and Bremner [43]. Soils $(1 \mathrm{~g})$ were added to the modified universal buffer (MUB, $4 \mathrm{~mL}$ ), toluene $(0.25 \mathrm{~mL})$, and p-nitrophenyl phosphate $(\mathrm{PNP}, 1 \mathrm{~mL})$ solution, and incubated at $37^{\circ} \mathrm{C}$ for $1 \mathrm{~h}$. Calcium chloride $(0.5 \mathrm{M})$ and sodium hydroxide were added to the soil suspensions, filtered using a two-layer filter paper (Whatman, No. 2, Maidstone, UK), and measured at OD $420 \mathrm{~nm}$. For the EcoPlate assay, soil samples were prepared according to the manufacturer's instructions (Biolog, Catalog 1506, Hayward, CA, USA), and EcoPlates were measured every $24 \mathrm{~h}$ for five days using a microplate reader (Infinite M200 Pro, TECAN).

Shannon diversity index was calculated formula as follows [44]:

$$
\text { Shannon diversity index: } \sum \mathrm{P}_{\mathrm{i}} \times\left(\ln \mathrm{P}_{\mathrm{i}}\right)
$$

Pi: the OD 590 value for i divided by the mean OD 590 value of the 31 wells.

\subsection{Statistical Analyses}

Statistical analysis of the data was conducted using Statistical Analysis Systems (SAS Institute, Cary, NC, USA). For the analysis of ordinal data, nonparametric analysis was used based on the ranks of the data, while percentage data were statistically analyzed after arcsine square root transformation. All data from repeated experiments were pooled after checking the homogeneity of variances with Levene's test and performing further statistical analyses. Analysis of variance was performed using general linear model procedures, and means were separated using the least significant difference (LSD). AUDPC was determined using the formula described by Shaner and Finney [45]: AUDPC $=\left(X_{i+1}+X_{i}\right)\left(t_{i+1}-t_{i}\right) / 2$, where $X_{i}$ is the disease severity or incidence at the ith observation, $t_{i}$ is the time (day) at the ith observation, and $\mathrm{n}$ is the total number of observations. All results are shown as the mean \pm standard error.

\section{Results}

\subsection{Cell Viability and Cellulase Test}

A total of 95 bacterial strains were isolated from various parts of vegetables, and cell-free supernatants were used in this study. A total of 27 out of the 95 bacterial supernatants were pre-selected based on more than $50 \%$ relative reduction in $\mathrm{Cmm}$ viability, and 42 supernatants contained cellulase activity on CMC media (Table 3). Among the 42 supernatants, only 7-strains GLSH03, H2-7, H8-1, HN05, HN12, K203, and TS3-1-had activities responsible for both the inhibition of $\mathrm{Cmm}$ viability and cellulase activity. 
Table 3. Relative cell viability and cellulase activity of Clavibacter michiganensis subsp. michiganensis.

\begin{tabular}{|c|c|c|c|c|c|c|c|c|c|c|c|}
\hline $\begin{array}{l}\text { Treat- } \\
\text { ments }\end{array}$ & $\begin{array}{c}\text { Inhibition of } \\
\text { Cmm } \\
\text { Viability }^{\text {a }}\end{array}$ & $\begin{array}{l}\text { Cellul- } \\
\text { ase Ac- } \\
\text { tivity }\end{array}$ & $\begin{array}{l}\text { Treat- } \\
\text { ments }\end{array}$ & $\begin{array}{c}\text { Inhibition of } \\
\text { Cmm } \\
\text { Viability }\end{array}$ & $\begin{array}{l}\text { Cellul- } \\
\text { ase Ac- } \\
\text { tivity }\end{array}$ & $\begin{array}{l}\text { Treat- } \\
\text { ments }\end{array}$ & $\begin{array}{c}\text { Inhibition of } \\
\text { Cmm } \\
\text { Viability }\end{array}$ & $\begin{array}{l}\text { Cellul- } \\
\text { ase Ac- } \\
\text { tivity }\end{array}$ & $\begin{array}{l}\text { Treat- } \\
\text { ments }\end{array}$ & $\begin{array}{c}\text { Inhibition of } \\
\text { Cmm } \\
\text { Viability }\end{array}$ & $\begin{array}{l}\text { Cellul- } \\
\text { ase Ac- } \\
\text { tivity }\end{array}$ \\
\hline GLSH03 & $98.32 \pm 0.22 *$ & - & TS6-3 & $57.15 \pm 1.42 *$ & + & GLS09 & $22.82 \pm 2.33 *$ & + & JC72 & $5.21 \pm 0.21$ & + \\
\hline HN12 & $98.27 \pm 0.12 *$ & - & JC35 & $53.70 \pm 1.62 *$ & + & GTH05 & $22.60 \pm 2.55$ * & - & GLCH05 & $4.85 \pm 0.07$ & + \\
\hline H8-1 & $98.06 \pm 0.03 *$ & - & TS5-2 & $51.78 \pm 2.15 *$ & + & JTL04 & $22.10 \pm 3.22 *$ & - & JC39 & $1.35 \pm 0.30$ & - \\
\hline JC34 & $97.91 \pm 0.11$ * & + & MB7-3 & $48.88 \pm 2.40 *$ & - & JTL08 & $21.54 \pm 3.27$ * & - & JC18 & $-1.66 \pm 6.73$ & + \\
\hline K203 & $97.71 \pm 0.26 *$ & - & JC46 & $45.07 \pm 0.62 *$ & + & JC54 & $20.82 \pm 1.91$ * & + & H19-1 & $-3.15 \pm 1.49$ & + \\
\hline $\mathrm{H} 2-7$ & $97.51 \pm 0.07^{*}$ & - & GLSH04 & $41.65 \pm 1.99$ * & - & GCH09 & $20.61 \pm 2.20$ * & + & JC55 & $-3.82 \pm 3.06$ & + \\
\hline $\begin{array}{l}5 \mathrm{GH} \\
41-08\end{array}$ & $97.39 \pm 0.02 *$ & + & GLSH01 & $41.60 \pm 0.68 *$ & - & HN02 & $18.61 \pm 2.86 *$ & - & $\mathrm{JC} 12$ & $-3.84 \pm 0.02$ & - \\
\hline $\mathrm{H} 24-9$ & $96.82 \pm 0.15 *$ & + & H18-10 & $41.30 \pm 1.81 *$ & - & HN09 & $18.29 \pm 3.71 *$ & - & HN20 & $-4.48 \pm 3.90$ & + \\
\hline TS3-1 & $95.76 \pm 0.26 *$ & - & GLCH06 & $40.31 \pm 0.75 *$ & - & HN11 & $17.73 \pm 3.58$ * & - & JC26 & $-12.20 \pm 4.67$ & - \\
\hline HN05 & $95.31 \pm 0.06^{*}$ & - & JC41 & $37.56 \pm 1.21$ * & - & MB7-1 & $16.88 \pm 5.41 *$ & - & HN29 & $-12.50 \pm 6.38$ & - \\
\hline GTH01 & $92.78 \pm 1.51$ * & + & GLSH06 & $36.89 \pm 2.63 *$ & - & GLSH10 & $16.83 \pm 1.02 *$ & + & 5GH31-15 & $-14.71 \pm 5.85$ & + \\
\hline JC33 & $90.61 \pm 0.81$ * & + & TS7-2 & $34.92 \pm 1.19$ * & + & JC16 & $16.73 \pm 3.39$ * & - & H12-10 & $-15.01 \pm 5.40$ & + \\
\hline H8-5 & $76.80 \pm 1.92 *$ & + & H6-4 & $34.65 \pm 3.70 *$ & - & GLC09 & $16.66 \pm 2.18 *$ & - & H1-2 & $-17.21 \pm 3.61$ & + \\
\hline H33-8 & $74.94 \pm 1.91 *$ & + & GCH06 & $34.58 \pm 1.57$ * & + & GCH05 & $16.24 \pm 0.88$ * & + & JTL02 & $-17.66 \pm 0.42$ & - \\
\hline TS6-1 & $71.41 \pm 0.76^{*}$ & + & JC53 & $33.38 \pm 3.67 *$ & - & H6-7 & $15.86 \pm 5.30$ & - & H1-1 & $-23.42 \pm 1.84$ & - \\
\hline $\mathrm{K} 204$ & $69.73 \pm 0.19 *$ & + & GLSH08 & $32.97 \pm 4.06$ * & - & GLCH04 & $14.14 \pm 3.99$ & + & JTL05 & $-23.48 \pm 5.89$ & - \\
\hline $\begin{array}{l}5 \mathrm{GH} \\
41-07\end{array}$ & $69.16 \pm 0.47^{*}$ & + & H23-8 & $32.76 \pm 3.50 *$ & + & H20-5 & $13.95 \pm 3.62$ & + & JTL03 & $-26.26 \pm 3.37$ & - \\
\hline H30-3 & $68.37 \pm 1.49 *$ & + & HN10 & $29.51 \pm 0.34$ * & - & HN24 & $12.37 \pm 5.06$ & + & H1-8 & $-29.74 \pm 2.09$ & + \\
\hline MB5-1 & $67.85 \pm 0.76^{*}$ & + & JC08 & $28.35 \pm 3.20 *$ & - & GLSH09 & $12.29 \pm 4.50$ & - & $\mathrm{JC} 27$ & $-31.48 \pm 4.00$ & + \\
\hline GLC02 & $63.71 \pm 1.89 *$ & + & GLCH09 & $26.76 \pm 5.73 *$ & + & HN22 & $10.03 \pm 4.10$ & - & $\mathrm{JC} 28$ & $-40.70 \pm 3.22$ & + \\
\hline H30-6 & $60.23 \pm 1.82 *$ & + & HN03 & $26.18 \pm 3.15$ * & + & GLCH03 & $10.01 \pm 3.98$ & + & JTL06 & $-55.43 \pm 6.10$ & - \\
\hline MB7-5 & $59.51 \pm 0.66$ * & + & HN08 & $26.18 \pm 1.49$ * & + & JC59 & $9.82 \pm 1.73$ & + & JTR09 & $-55.44 \pm 1.89$ & + \\
\hline K185 & $58.63 \pm 2.05 *$ & + & HN25 & $24.06 \pm 4.56 *$ & + & JTR01 & $9.48 \pm 4.28$ & - & GLSH11 & $-72.94 \pm 5.66$ & - \\
\hline H15-2 & $58.19 \pm 2.66^{*}$ & + & $\mathrm{H} 5-9$ & $23.58 \pm 3.64$ * & - & GC03 & $6.58 \pm 1.68$ & + & & & \\
\hline
\end{tabular}

a: Relative reduction in cell viability (\%) of $C$. michiganensis subsp. michiganensis $(\mathrm{Cmm})$ treated with tenfold-diluted supernatant; +: production of cellulase was higher than in non-treated $\mathrm{Cmm}$; -: production of cellulase was lower than that in non-treated Cmm. An asterisk means statistical difference compared to controls, based on LSD $(p<0.05)$.

\subsection{Disease Suppressive Activity}

Among the seven bacterial supernatants, GLSH03, H8-1, and K203 supernatants significantly $(p<0.05)$ suppressed disease incidence compared to water and $1 / 10$-diluted media controls (Figure S1). Percentages of plant wilting were $73.96 \pm 5.91$ and $67.71 \pm 4.68$ in water and media controls, respectively, whereas disease incidence in plants treated with supernatants of GLSH03, H8-1, and K203 was $40.63 \pm 2.13,43.75 \pm 4.27$, and $43.75 \pm 2.28$, respectively. The results of AUDPC tended to be similar to those of disease incidence (Figure S1). Supernatants of GLSH03, H8-1, K203, and streptomycin as a positive control showed significant differences from the controls. The AUDPC was $484.38 \pm 43.89$ in control (media) plants, while it was $353.13 \pm 34.83,287.33 \pm 28.37$, and $354.17 \pm 28.76$ in supernatants of GLSH03-, H8-1-, and K203-treated plants, respectively (Figure S1).

\subsection{Bacterial Identification by $16 S$ rRNA Gene Sequencing and Characterization}

Strains GLSH03, H8-1, and K203 belong to the genus Bacillus, based on 16s rRNA sequence analysis (Figure S2). As a result of comparison with sequences of type strains, the GLSH03 (1457 bp) showed $99.86 \%$ similarity to Bacillus velezensis (CR502 $\left.{ }^{\mathrm{T}}, \mathrm{AY} 603658\right)$, while K203 (1435 bp) and H8-1 (1428 bp) exhibited $99.86 \%$ and 100\% similarity to B. siamensis $\left(\mathrm{KCTC}_{13613}{ }^{\mathrm{T}}, \mathrm{AJVF} 01000043\right)$ and B. aryabhattai (B8W22 $\left.{ }^{\mathrm{T}}, \mathrm{EF} 114313\right)$, respectively (Figure S2). To confirm their characteristics and classification, biochemical tests were performed using API 50CH/B and API ZYM. It was found that 17 types (glycerol, L-arabinose, D-glucose, D-fructose, inositol, D-mannitol, etc.) could be used in all tested strains (Table S1). In contrast, $d$-arabinose, l-xylose, methyl- $\beta$-d-xylopyranoside, and methyl- $\alpha$-d-mannopyranoside could not be used in any strain. Three strains-GLSH03, H8-1, and K203-used esterase (C4) and esterase lipase (C8); however, 12 enzymes, including lipase and leucine arylamidase, were not available (Table S2).

\subsection{Bioactive Extracts Derived from Bacterial Supernatants}

As a result of measuring the viability of $\mathrm{Cmm}$ treated with solvent or water extracts of bacterial supernatants, the water extracts of GLSH03, H8-1, and K203 showed inhibitory activity against $\mathrm{Cmm}$ viability. However, no activity was shown for any of the tested solvent extracts (data not shown). Regression curves of water extracts of GLSH03, H8-1, 
and K203 were $y=0.00000224 x^{2}-0.0005 x+0.8223, y=0.0000018 x^{2}-0.0041 x+0.6891$, and $y=0.00000336 x^{2}-0.0055 x+0.8281$; the minimum inhibitory concentrations (MICs) of water extracts of GLSH03, H8-1, and K203 were $180.89 \mathrm{mg} / \mathrm{mL}, 157.24 \mathrm{mg} / \mathrm{mL}$, and $138.51 \mathrm{mg} / \mathrm{mL}$, respectively, while their lethal doses $\left(\mathrm{LD}_{50}\right)$ were $124.86 \mathrm{mg} / \mathrm{mL}, 81.15 \mathrm{mg} / \mathrm{mL}$, and $72.02 \mathrm{mg} / \mathrm{mL}$, respectively (data not shown).

\subsection{Biocontrol Activity in Plant Assays}

For determination of concentration for biocontrol assays in tomato plants, various concentrations $(0,10,100$, and $1000 \mu \mathrm{g} / \mathrm{g})$ of three bacterial water extracts were tested. When the water extracts of H8-1 and K203 at $1000 \mu \mathrm{g} / \mathrm{g}$ were used, the disease incidence and severity were the most effectively suppressed, with control efficacies of $79.17 \%$ and $68.73 \%$ compared to the control, respectively (Figure S3). However, water extract of GLSH03 had suppressive activity on disease severity at only $10 \mu \mathrm{g} / \mathrm{g}$ (Figure S3). Disease incidence in tomato plants treated with water extracts of H8-1 and K203 was $58.33 \pm 6.18$ and $58.33 \pm 2.63$, respectively, and $79.17 \pm 4.17$ in control plants. Disease severity and the AUDPC of both also showed a significant difference in all treatments compared to the control, except for the AUDPC of disease incidence in the K203 treatment (Figure 1). As a result of the plant growth promotion test, there was a significant increase in K203water-extract-treated plants compared to controls. In contrast, H8-1 was not different from controls. Shoot weights were $65.75 \pm 4.34 \mathrm{~g} /$ plant in control plants, $68.83 \pm 3.57 \mathrm{~g} / \mathrm{plant}$ in H8-1-, and $78.27 \pm 2.30 \mathrm{~g} /$ plant in K230-water-extract-treated plants, which was a 1.19-fold increase compared to the controls (Figure S4).
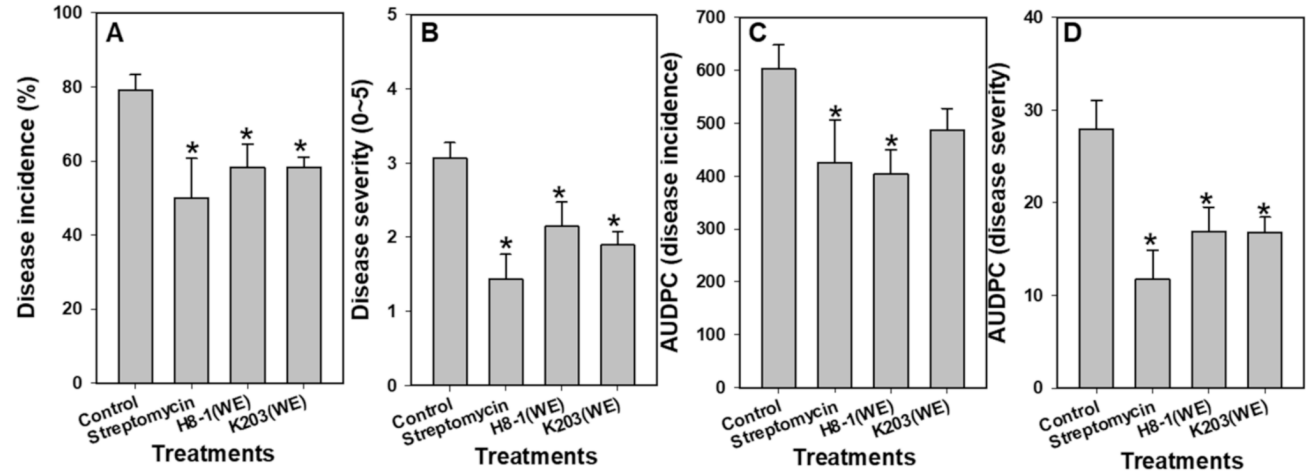

Figure 1. Disease incidence (A), severity (B), and area under the disease progress curve (AUDPC) $(\mathbf{C}, \mathbf{D})$ caused by Clavibacter michiganensis subsp. michiganensis $(\mathrm{Cmm})$ in tomato plants. The mixtures of the water extracts and pathogen suspensions were treated in pots (final concentration: water extract, $1000 \mu \mathrm{L} / \mathrm{g}$ of soil, $\mathrm{Cmm}, 10^{9} \mathrm{cfu} / \mathrm{g}$ of soil). An asterisk on the bar indicates statistically significant difference compared to controls based on LSD $(p<0.05)$; error bars indicate standard errors ( $n=6 ; 3$ replicates of 8 plants per treatment). WE: water extract.

\subsection{Colonization of Cmm in Tomato Plants}

Based on Cmm colony counting as intervals of time and location of nodes in tomato plants, treatment with water extracts of H8-1 and K203 suppressed colonization of Cmm in tomato plants at 20 days after inoculation (Figure 2). One day after inoculation, $\mathrm{Cmm}$ was not detected in any node of tomato plants; three days after inoculation, $\mathrm{Cmm}$ was detected in the first and second nodes of all treated plants (Figure S5). However, when tomato plants were treated with the water extract of H8-1 and streptomycin, the population of Cmm in the first and second nodes was significantly reduced compared to the controls (Figure S5). Seven days after inoculation, the $\mathrm{Cmm}$ population in tomato plants treated with the water extract of H8-1 and streptomycin was significantly $(p<0.05)$ reduced compared to that in the control plants (Figure S5). Cmm colonized in the apex of tomato plants at 15 days after inoculation; first, fourth, and apex nodes of tomato plants treated with water extract of H8-1 differed significantly from controls (Figure S5). Twenty days after inoculation, the $\mathrm{Cmm}$ population was significantly reduced in the fourth node of the K203-water-extract- 
and streptomycin-treated plants, and in the apex of the H8-1- $(1.73 \pm 0.02)$ and K203$(1.75 \pm 0.04)$ water-extract-treated plants, compared to the controls (2.38 \pm 0.06$)$ (Figure 2).

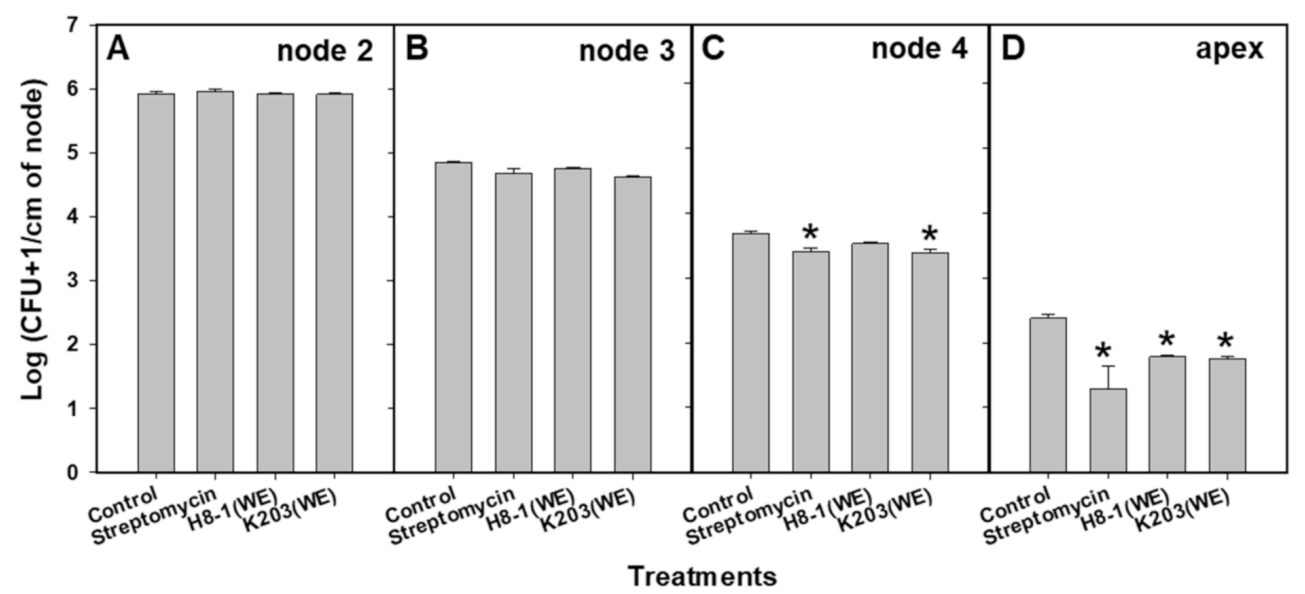

Figure 2. Colonization of $\mathrm{Cmm}$ in tomato plants at 20 days after inoculation. Stem segments (node 2 (A), node 3 (B), node 4 (C), and apex (D)) were homogenized and cultured on bacterial canker of tomato $(\mathrm{BCT})$ media. An asterisk on the bar indicates significant statistical difference compared to controls, based on LSD $(p<0.05)(n=10)$. WE: water extract.

\subsection{Antioxidant Enzyme Activity in Tomato Plants}

Under non-inoculated conditions, water extracts of H8-1 and K203 tended to increase the levels of antioxidant enzymes-including peroxidase, glutathione peroxidase, and catalase-compared to the controls (Figure 3). Under Cmm-inoculated conditions, peroxidase activity in the H8-1-water-extract-treated plants at 5 and 10 DAI was $129.0 \%$ and $188.4 \%$ higher than in control plants; the activity in the K203-water-extract-treated plants at 5,7 , and 10 DAI increased by 148.8, 180.5, and 197.6\%, respectively, compared to control plants. Glutathione peroxidase activity at $5 \mathrm{DAI}$ in H8-1-treated plants, and 7 and $10 \mathrm{DAI}$ in K203-treated plants, was significantly $(p<0.05)$ increased compared to control plants. Catalase activity increased only in the water extract of the H8-1-treated plants at 7 and 10 DAI compared to the control plants. However, superoxide dismutase activity did not show any difference between treatments in Cmm-inoculated plants (Figure 3).

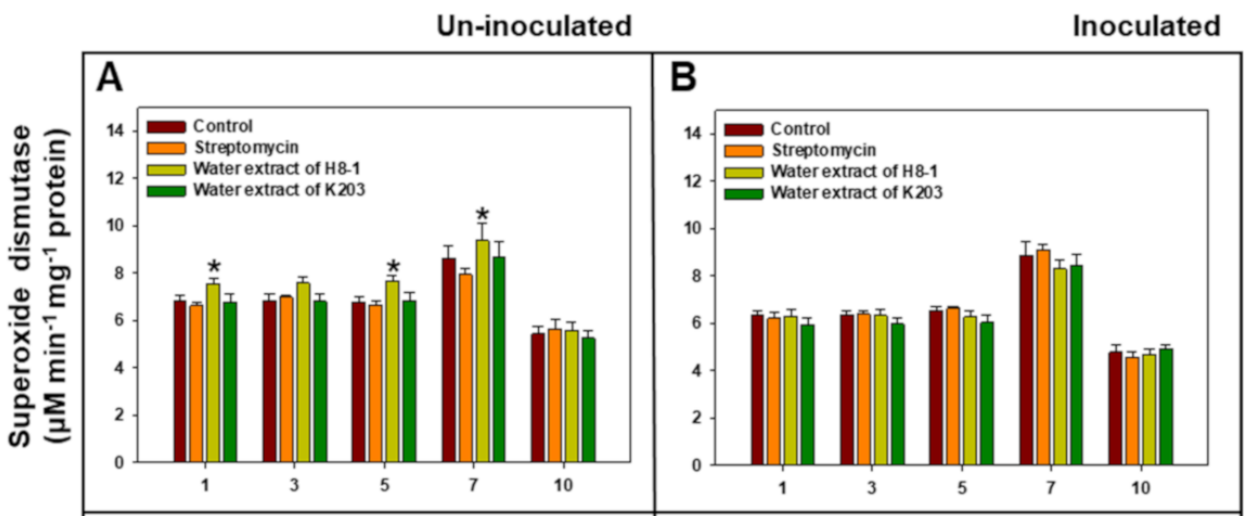

Figure 3. Cont. 


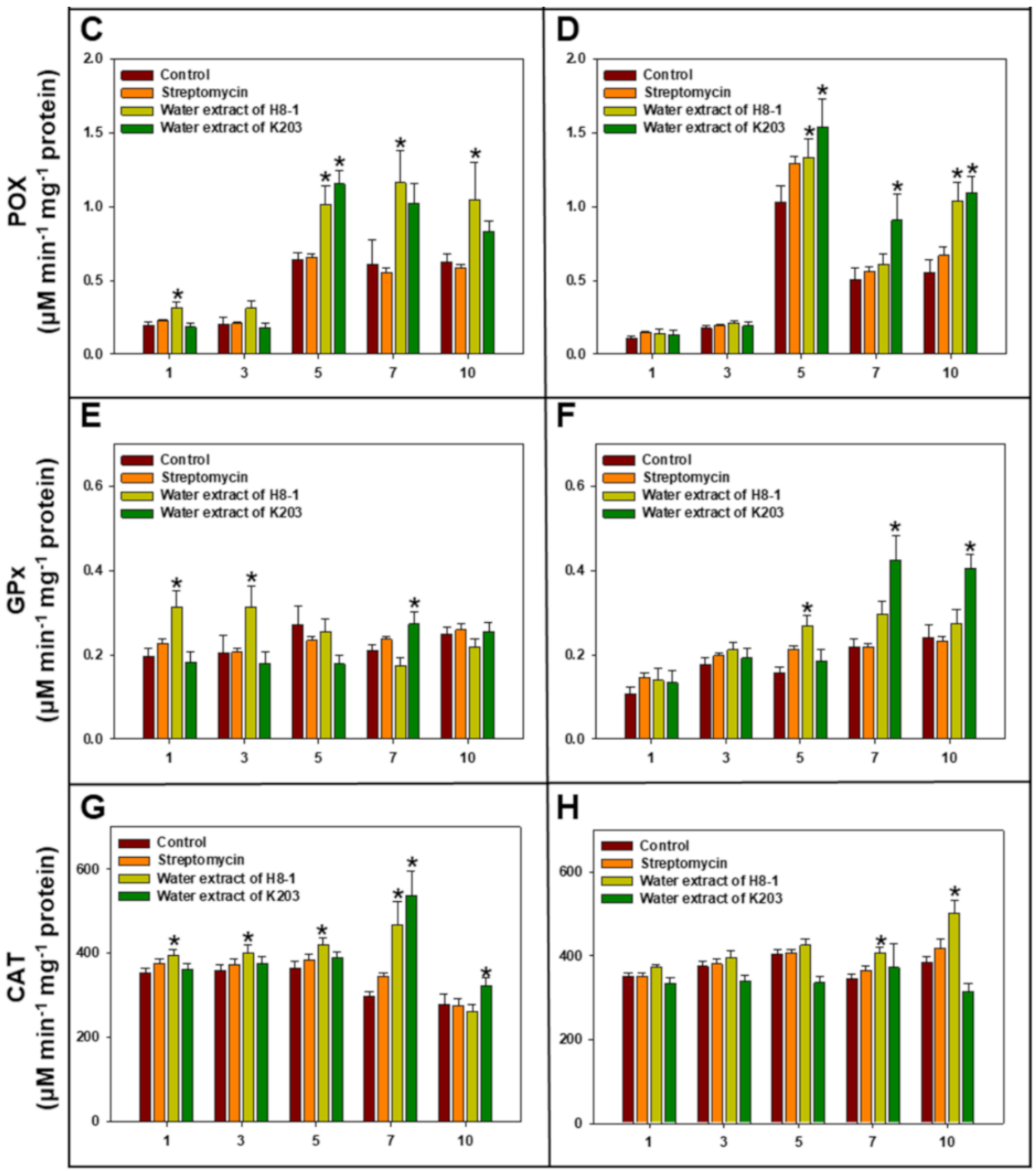

Days after inoculation

Figure 3. Activity of antioxidant enzymes such as superoxide dismutase (A,B), peroxidase (C,D), glutathione peroxidase $(\mathbf{E}, \mathbf{F})$, and catalase $(\mathbf{G}, \mathbf{H})$ by days after un- $(\mathbf{A}, \mathbf{C}, \mathbf{E}, \mathbf{G})$ or inoculation $(\mathbf{B}, \mathbf{D}, \mathbf{F}, \mathbf{H})$ of Clavibacter michiganensis subsp. michiganensis $(\mathrm{Cmm})$. An asterisk on the bar indicates statistically significant difference compared to controls on each day after inoculation, based on LSD $(p<0.05)$; error bars indicate standard errors $(n=10)$.

\subsection{Cmm Pathogenicity-Related Gene Expression}

The effect of the selected water extracts on the expression of the $\operatorname{celA}, \operatorname{celB}$, pat1, $\operatorname{ch} p$, ppaA, and pelA1 genes of $\mathrm{Cmm}$ was evaluated by qRT-PCR (Figure 4). When $\mathrm{Cmm}$ was treated with water extracts of $\mathrm{H} 8-1$ and $\mathrm{K} 203$, the relative gene expressions of $c e l A, c e l B$, pat1, and pelA1 were significantly $(p<0.05)$ reduced compared to the controls at $72 \mathrm{~h}$ after treatment (HAT). Relative expression of celA was suppressed by 0.41-fold in H8-1water-extract-treated $\mathrm{Cmm}$ and 0.45-fold in K203-water-extract-treated $\mathrm{Cmm}$ at $72 \mathrm{HAT}$; celB was less expressed by 0.01-fold in H8-1-water-extract-treated $\mathrm{Cmm}$ and 0.02 -fold in K203-water-extract-treated $\mathrm{Cmm}$ at $72 \mathrm{HAT}$. In the case of pat1 and pelA1 gene expression at 72 HAT, when treated with water extract of H8-1, their expression was reduced by $0.15-$ and 0.14-fold, respectively; when treated with water extract of K203, both were decreased by 0.13 -fold. The $p p a A$ gene expression of $\mathrm{Cmm}$ was significantly $(p<0.05)$ decreased in treatments of H8-1 water extract and streptomycin at 72 HAT. Streptomycin, as a positive control, reduced the relative expression of the $c e l A, c e l B$, pat $1, \operatorname{ch} p C, p p a A$, and pelA genes of Cmm at 72 HAT (Figure 4). 


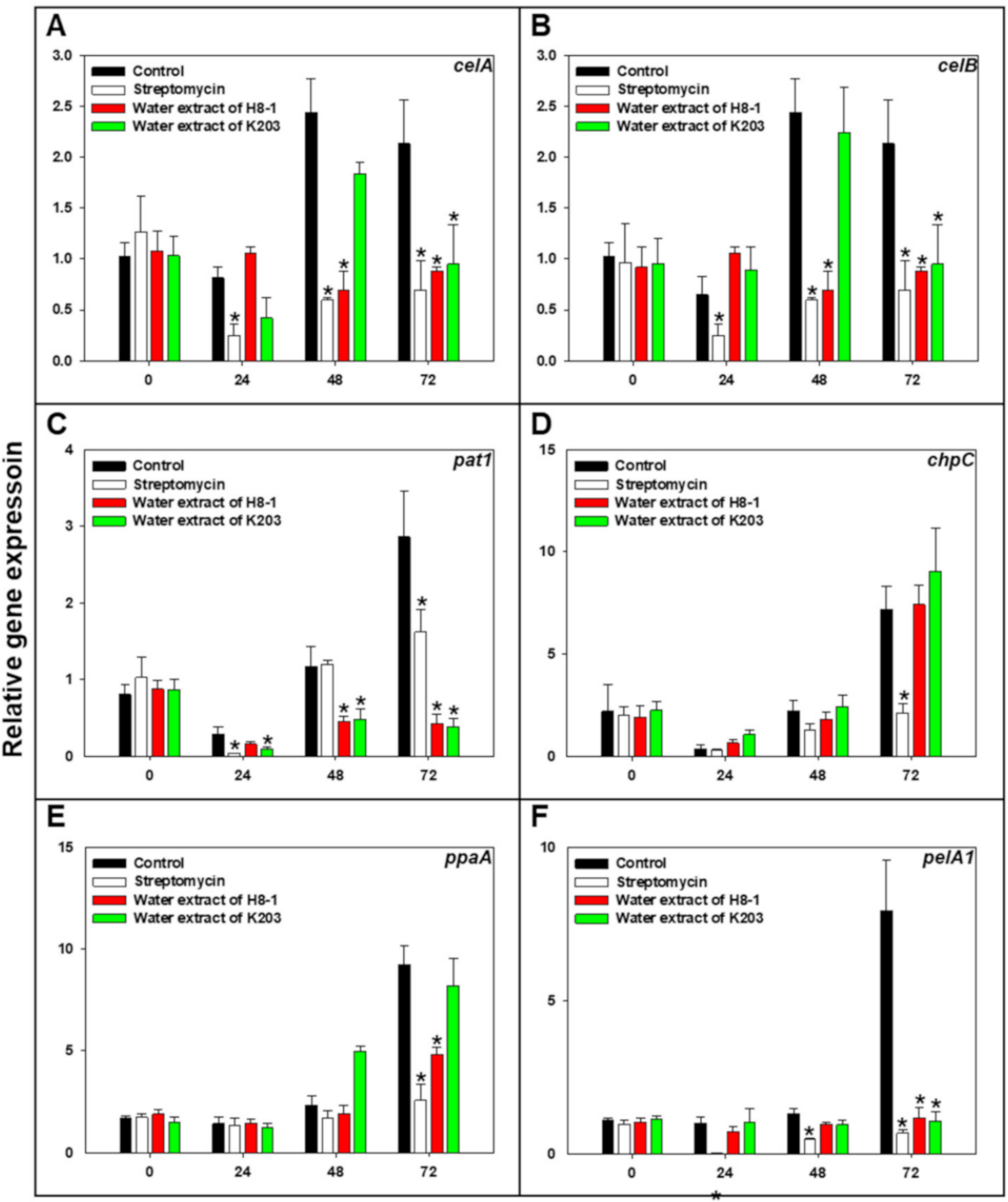

Hours after treatment

Figure 4. Relative transcript levels of celA (A), celB (B), pat1(C), $\operatorname{chpC}(\mathbf{D}), p p a A(\mathbf{E})$, and pelA1 (F) were determined by quantitative real-time polymerase chain reaction at various hours after treatment. Relative gene expression of Clavibacter michiganensis subsp. michiganensis ( $\mathrm{Cmm}$ ) grown in M9 medium amended with carboxymethyl cellulose (CMC) was normalized with gyrA. An asterisk on the bar indicates statistically significant difference compared to controls at each hour after treatment, based on LSD $(p<0.05)$; error bars indicate standard errors $(n=8)$.

\subsection{Relative Expression of Plant Genes, including ACO, PI2, and PR1a}

Under non-inoculated conditions, the relative expression of ACO and PI2 did not differ between treatments; however, under $C m m$-inoculated conditions, water extracts of H8-1 and K203 decreased the gene expression of ACO compared to the control at $72 \mathrm{HAI}$ (Figure 5). PI2 gene expression was increased significantly by treatment with H8-1 water extract at 72 HAI in Cmm-inoculated plants. In H8-1- and K203-water-extract-treated plants, PR1a was expressed more highly than in control plants at $72 \mathrm{HAI}$, in both noninoculated and inoculated conditions (Figure 5). As a comparison of non-inoculation and $\mathrm{Cmm}$ inoculation, when plants were inoculated with $\mathrm{Cmm}$, tomato $A C O$ and PR1a genes' expression was increased, while PI2 expression did not show any differences. As a result of the plant gene expression, water extracts of H8-1 and K203 reduced ACO expression, and further enhanced PR1a gene expression compared to controls under Cmm inoculation. 

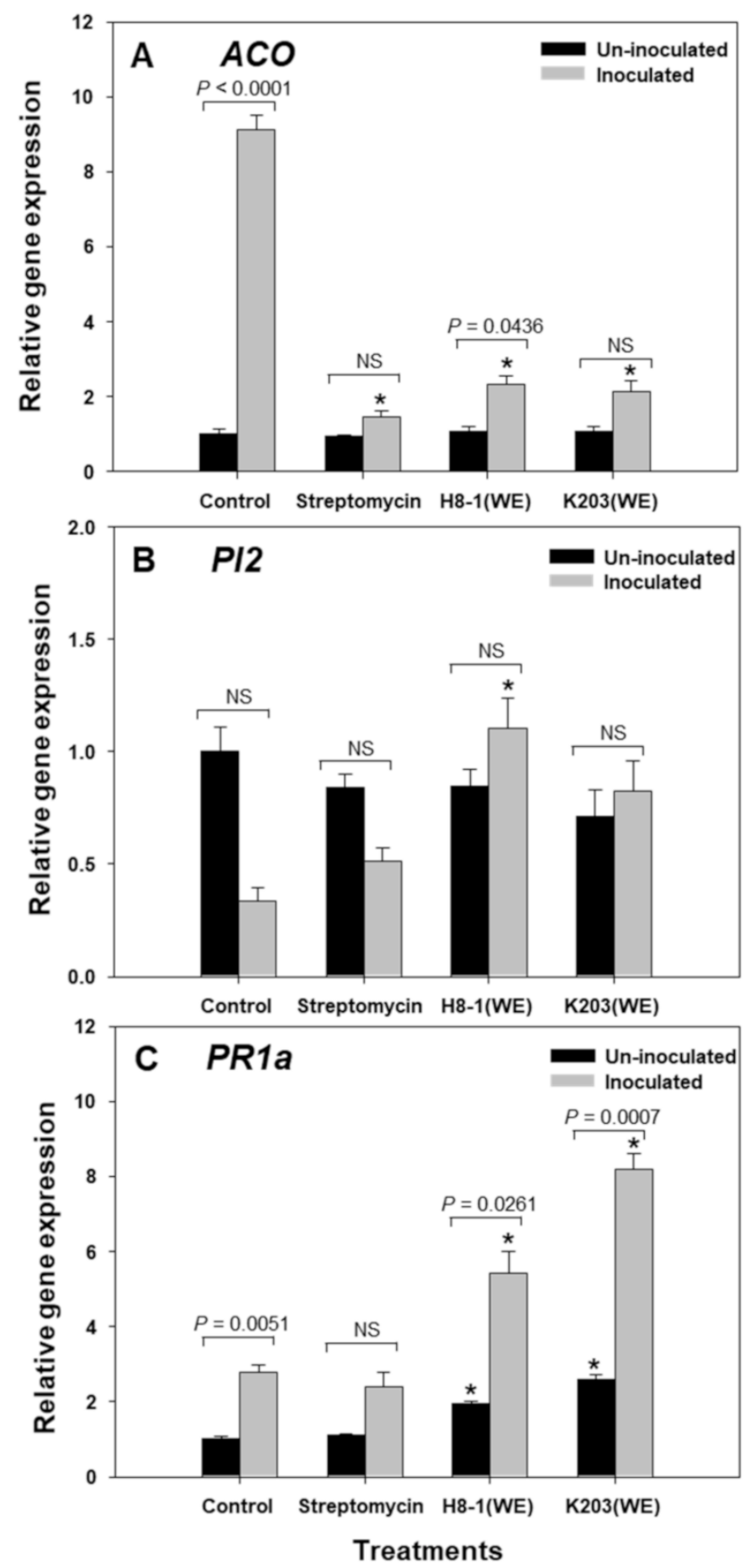

Figure 5. Relative transcript levels of $A C O(\mathbf{A}), P I 2(\mathbf{B})$, and $P R 1 a(\mathbf{C})$ were determined by quantitative real-time polymerase chain reaction at $72 \mathrm{~h}$ after inoculation (HAI). Relative expression levels of $A C O, P I 2$, and PR1a in Clavibacter michiganensis subsp. michiganensis (Cmm)-infected plants were normalized with GAPDH. An asterisk on the bar indicates statistically significant difference between treatments in inoculated or non-inoculated plants, based on LSD $(p<0.05) ; p$-values on the bars represent comparisons between non-inoculated and inoculated plants; error bars indicate standard errors $(n=8)$. NS: not significant.

\subsection{Soil Microbial Activity}

Total microbial activity assayed by fluorescein diacetate hydrolysis in tomato-grown soils treated with the K203 water extract showed higher levels than the controls 15 days 
after inoculation (DAI), whereas, in the case of H8-1, soil microbial activity was increased regardless of $\mathrm{Cmm}$ inoculation compared to that of the controls 20 DAI (Figure 6). Under $\mathrm{Cmm}$-inoculated and non-inoculated conditions, soil acid phosphatase activity was not significantly different between water extracts and controls, except at 5 DAI in soils inoculated with $\mathrm{Cmm}$. Urease activity in soils treated with water extracts of H8-1 and K203 was higher than that in the controls during the test period, regardless of Cmm inoculation (Figure 6). In contrast, when soils were treated with streptomycin, the soil acid phosphatase and urease activities were lower than those of the controls. As a result of community analysis using Biolog EcoPlate ${ }^{\mathrm{TM}}$ based on the influence of microbial carbon substrate use, the Shannon index for species diversity significantly increased when water extracts of H8-1 and K203 were used for treatment, regardless of $\mathrm{Cmm}$ inoculation; however, streptomycin-treated soils had reduced community diversity compared to the controls (Figure 7).

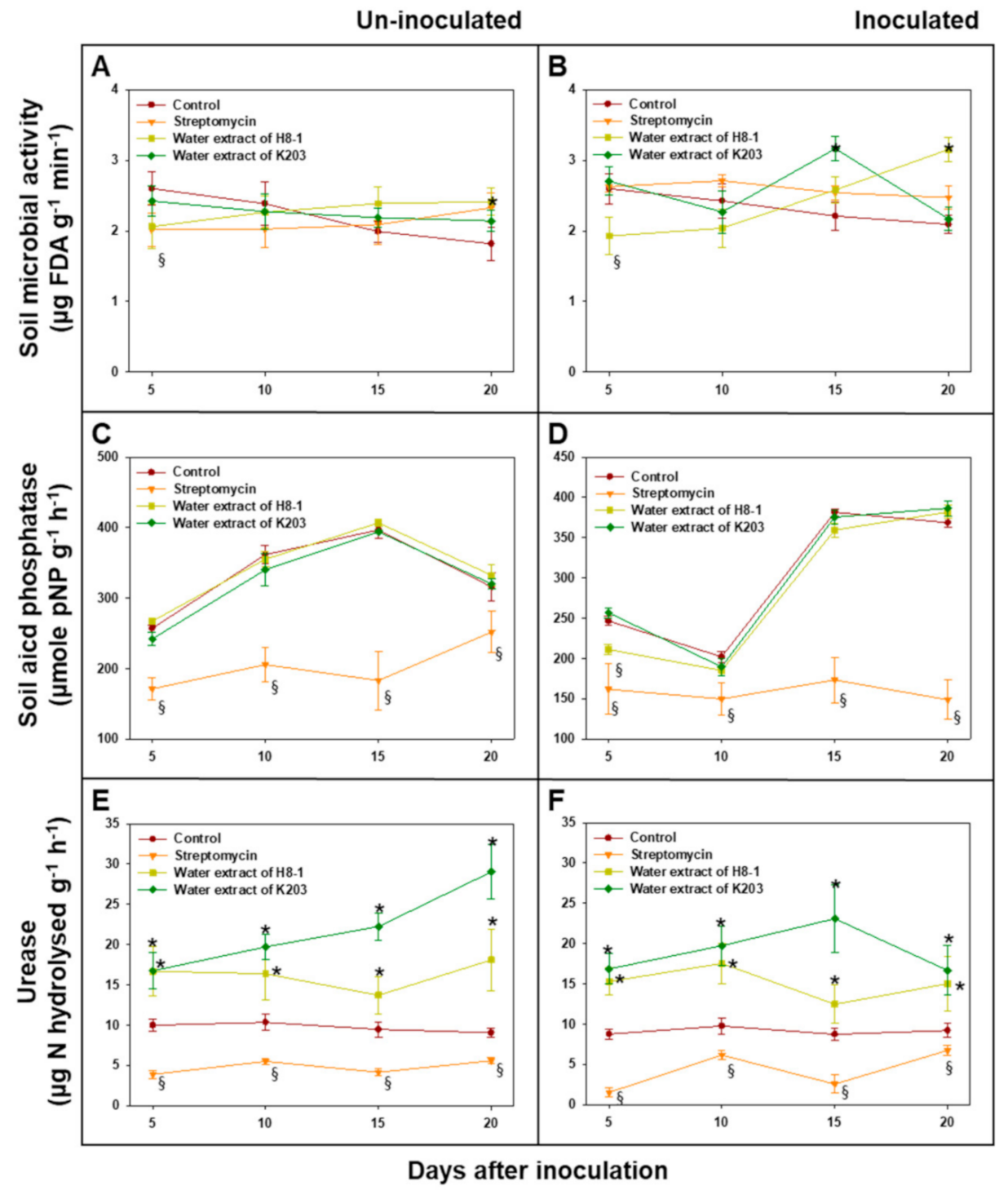

Figure 6. Total microbial activity (A,B) and soil enzyme activity such as acid phosphatase (C,D), and urease $(\mathbf{E}, \mathbf{F})$ by days after un- $(\mathbf{A}, \mathbf{C}, \mathbf{E})$ or inoculation $(\mathbf{B}, \mathbf{D}, \mathbf{F})$ with Clavibacter michiganensis subsp. michiganensis $(\mathrm{Cmm})$ and extract treatment in tomato plants. Asterisks and $\S$ on the bar indicate statistically significant differences as higher and less than controls, based on LSD $(p<0.05)$, respectively; error bars indicate standard errors $(n=10)$. 

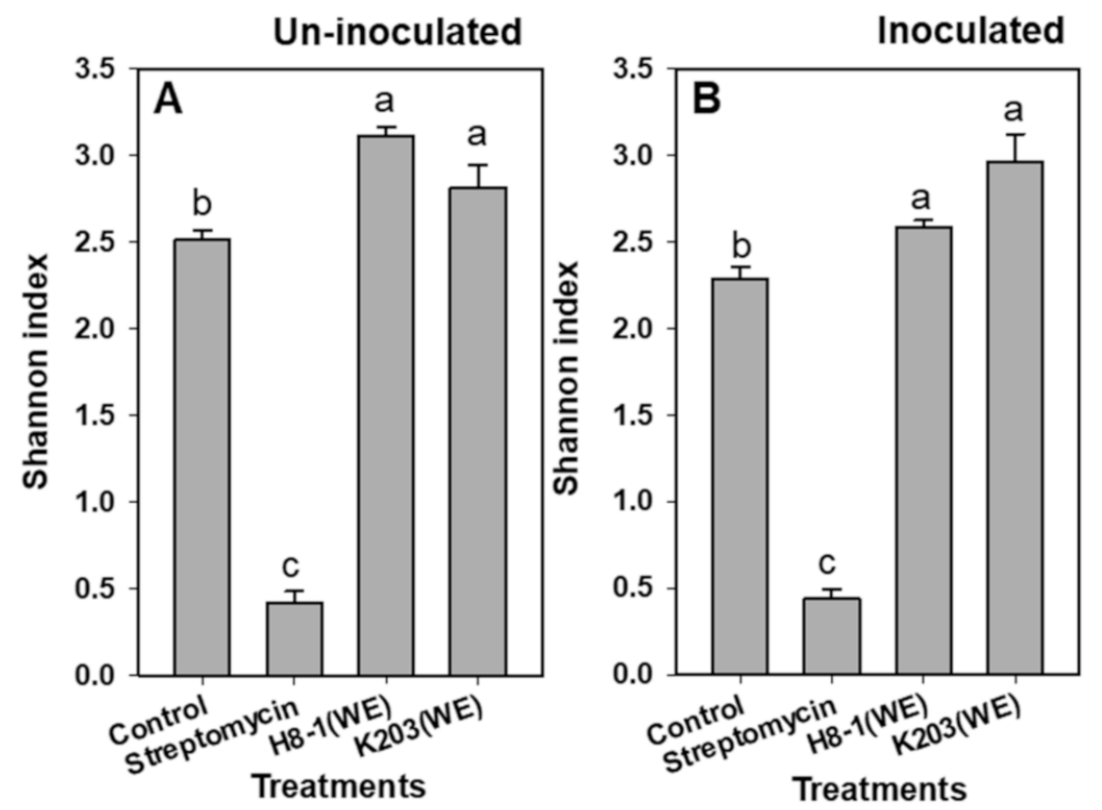

Figure 7. Shannon's diversity index based on EcoPlates of rhizosphere soils taken from Clavibacter michiganensis subsp. michiganensis $(\mathrm{Cmm})$ un- $(\mathbf{A})$ or inoculated $(\mathbf{B})$ tomato plants. The final values of each well at $72 \mathrm{~h}$, where $\mathrm{H}=-\sum(\mathrm{Pi} \times \ln \mathrm{Pi})$, and $\mathrm{Pi}$ is the proportional optical density value of each well. The small letters $(\mathrm{a}-\mathrm{c})$ on the bar indicate statistically significant differences based on LSD $(p<0.05)$; error bars indicate standard errors $(n=10)$.

\section{Discussion}

In this study, we found that bioactive water extracts derived from Bacillus strains H8-1 and K203 suppressed tomato wilt caused by Cmm. The two bacterial supernatants inhibited the C $\mathrm{Cm}^{\prime}$ 's viability and suppressed the secretion of cellulase, which is a pathogenic factor of $\mathrm{Cmm}$ [34]. When $\mathrm{Cmm}$ was treated with the extracts, the celA, celB (cellulase), pat1, and pelA1 (pectate lyase) of $\mathrm{Cmm}$ showed suppressed expression. In the plant assay, water extracts of H8-1 and K203 significantly reduced disease incidence and severity, together with reducing ethylene-related gene $(A C O)$ expression and increasing $P R-1 a$ gene expression. Moreover, the extracts tended to limit the colonization and development of $\mathrm{Cmm}$ in the upper part of the tomatoes' interior. Additionally, water extracts could affect the soil microbial activity and diversity.

The water extracts of H8-1 and K203 significantly suppressed tomato wilt caused by $\mathrm{Cmm}$ in the pot assay. This effect could be explained by the following factors: For successful infection of host plants, $\mathrm{Cmm}$ secretes various enzymes, including cellulase and pectate lyase [11]. Cmm has two major cellulase genes—celA and celB - and the pathogen uses the secretion enzymes to enter the host plant via maceration [3]. Previous studies have shown that celA is a major virulence factor that causes wilt in tomatoes, playing a pivotal role in virulence function and promoting host infection by $\mathrm{Cmm}[34,46]$. Supernatants containing water extracts of H8-1 and K203 directly reduced Cmm viability and cellulase activity. Moreover, the water extracts of H8-1 and K203 decreased the expression of Cmm genes, such as celA (cellulase), which is pivotal for entering tomato plants. Therefore, the water extracts of H8- 1 and K203 could decrease the possibility of infection by attenuating virulence functions such as cellulase activity or secretion. In addition to $c e l A$ and $c e l B$, expression of pat1 and pelA1 genes was also affected by the water extracts of H8-1 and K203. Like celA, pelA1 also participates in host cell degradation during host plant invasion [11]. Chalupowicz et al. [39] found that the transcription of chromosomal genes involved in cell wall degradation, such as pelA1 and $c e l B$, was induced during early infection, and proteases encoded by $p a t 1, \operatorname{ch} p C$, and $p p a A$ are involved in host colonization, acquisition of the pathogen's nutrient sources, and attenuation of host defenses $[10,11]$. According to the results of Stork et al. [47] and Chalupowicz et al. [6], mutation of $\operatorname{chpC}$-which participates 
in both virulence and colonization-dramatically decreases disease, limiting it to only weak symptoms. In addition to the effects on $\mathrm{Cmm}$ virulence gene expression, when both water extracts were used, Cmm was restricted in colonization and development in the tomatoes' interior, from the root to the upper node of the stem. Therefore, the water extracts of H8-1 and K203 might affect Cmm virulence gene expression related to cell degradation enzymes, such as cellulase and protease, restricting the colonization and development of $\mathrm{Cmm}$ in the xylem of tomato plants, as well as infection.

The water extracts of H8-1 and K203 affected the plant-defense-related responses. Antioxidant enzyme levels were increased regardless of $\mathrm{Cmm}$ inoculation in the waterextract-treated-plants; similarly, when DL- $\beta$-aminobutyric acid or acibenzolar-S-methyl were added, the levels of reactive oxygen species (ROS)-scavenging antioxidant systems -including peroxidase, phenylalanine ammonia-lyase, and glutathione peroxidase-were increased [33,48,49]. Antioxidant enzymes also play important roles in the reinforcement of plant cell walls by increasing phenols and lignin; consequently, they can act as a physical barrier against penetration by cell wall degradation enzymes of Cmm [50]; therefore, the treatments with water extracts can help to enhance plant defense against $\mathrm{Cmm}$ infection by increasing antioxidant enzyme activities. Meanwhile, water extracts can also alter the expression of plant genes, such as PR1a, PI2, and ACO. Plant PR1a has been used as a marker gene for inducing salicylic acid (SA)-dependent resistance [51,52]. PR1a gene expression was significantly increased in the water-extract-treated plants; therefore, the extracts might enhance plant defense responses against $\mathrm{Cmm}$ via salicylic-acid-dependent pathways and suppress tomato wilt. The PI2 gene, which encodes a proteolytic enzyme inhibitor used as a jasmonic-acid-dependent marker gene, can be triggered by wounding [40]. In this study, the PI2 gene dramatically increased in plants treated with H8-1-water extract at $72 \mathrm{~h}$ after inoculation; therefore, H8-1-water extract can be involved in a jasmonic-aciddependent defense pathway. During $\mathrm{Cmm}$ infection, 1-aminocyclopropane-1-carboxylic acid (ACC)-oxidase as an ethylene-synthesizing enzyme was induced, and Cmm-triggered ethylene synthesis in host plants could be be one of the important factors in disease development [12,53]. As a result of ACO encoding 1-aminocyclopropane-1-carboxylic acid (ACC) oxidase expression, ACO gene expression significantly decreased in water-extracttreated plants, corresponding to disease suppression.

Additionally, the two extracts tended to increase the soil microbial activity, urease activity, and microbial diversity. This suggests that the water extract can affect soil microbial diversity, which can promote soil health correlated with microbial activity, without negative influence. The increase in shoot weight in water-extract-treated plants may also be related to the use of microbial carbon sources and soil urease activity [54]. Therefore, the extracts might affect soil microbial environments, and could indirectly affect soil-borne pathogens, such as Cmm. Here, the water extract of Bacillus strains H8-1 and K203 suppressed pathogenicity factors such as cell degradation enzymes of Cmm, which are necessary for infection, and diminished colonization and development into the xylem of tomato plants. Moreover, the extracts may affect the plants' ROS-scavenging systems involved in the defense response, and induce PR1a gene expression in a salicylic-aciddependent manner, as well as soil microbial activities. Taken together, the water extracts of H8-1 and K203 could directly inhibit Cmm and indirectly induce plant defense and affect soil microbial activities; therefore, the water extracts could be used as biocontrol agents for controlling tomato bacterial wilt caused by $\mathrm{Cmm}$.

Supplementary Materials: The following supporting information can be downloaded at: https: / / www.mdpi.com/article/10.3390/microorganisms10020403/s1, Figure S1: Disease suppression by bacterial supernatants in tomato plant, Figure S2: Phylogenetic analysis of 16S rRNA sequences of strains GLSH03, H8-1, and K203, Figure S3: Selection of water extract-concentration for controlling the disease caused by Clavibacter michiganensis subsp. michiganensis $(\mathrm{Cmm})$, Figure S4: Plant growth promotion by the water extract, Figure S5: Colonization of Clavibacter michiganensis subsp. michiganensis $(\mathrm{Cmm})$ in tomato plants, Table S1: API 50CH test of strains K203, H8-1 and GLSG03, Table S2: API ZYM test of strains K203, H8-1 and GLSH03. 


\begin{abstract}
Author Contributions: Conceptualization, M.K.S.; Formal analysis, H.J. and S.T.K.; Funding acquisition, M.K.S.; Investigation, H.J.; Methodology, S.T.K.; Resources, M.K.S.; Supervision, M.K.S.; Validation, M.K.S.; Writing—original draft, H.J.; Writing—review \& editing, M.K.S. All authors have read and agreed to the published version of the manuscript.
\end{abstract}

Funding: This research was supported by a research grant (Project No. 01497802) from the National Institute of Agricultural Sciences, Rural Development Administration, Korea.

Institutional Review Board Statement: Not applicable.

Informed Consent Statement: Not applicable.

Data Availability Statement: Not applicable.

Conflicts of Interest: The authors declare no conflict of interest.

\title{
References
}

1. FAO. FAOSTAT. 2020. Available online: http://www.fao.org/faostat/en/\#data/QC/visualize (accessed on 27 December 2021).

2. Al-Maawali, S.S.; Al-Sadi, A.M.; Ali Khalifa Alsheriqi, S.; Nasser Al-Sabahi, J.; Velazhahan, R. The potential of antagonistic yeasts and bacteria from tomato phyllosphere and fructoplane in the control of Alternaria fruit rot of tomato. All Life 2021, 14, 34-48. [CrossRef]

3. Eichenlaub, R.; Gartemann, K. The Clavibacter michiganensis subspecies: Molecular investigation of gram-positive bacterial plant pathogens. Annu. Rev. Phytopathol. 2011, 49, 445-464. [CrossRef] [PubMed]

4. Gartemann, K.; Kirchner, O.; Engemann, J.; Gräfen, I.; Eichenlaub, R.; Burger, A. Clavibacter michiganensis subsp. michiganensis: First steps in the understanding of virulence of a Gram-positive phytopathogenic bacterium. J. Biotechnol. 2003, 106, 179-191. [PubMed]

5. Sen, Y.; van der Wolf, J.; Visser, R.G.; van Heusden, S. Bacterial canker of tomato: Current knowledge of detection, management, resistance, and interactions. Plant Dis. 2015, 99, 4-13. [CrossRef] [PubMed]

6. Chalupowicz, L.; Barash, I.; Reuven, M.; Dror, O.; Sharabani, G.; Gartemann, K.; Eichenlaub, R.; Sessa, G.; Manulis-Sasson, S. Differential contribution of Clavibacter michiganensis ssp. michiganensis virulence factors to systemic and local infection in tomato. Mol. Plant Pathol. 2017, 18, 336-346. [PubMed]

7. Strider, D.L. Bacterial canker of tomato caused by Corynebacterium michiganense; a literature review and bibliography. NC Agric. Exp. Stat. Tech. Bull. 1969, 193.

8. Davis, M.J.; Gillaspie Jr, A.G.; Vidaver, A.K.; Harris, R.W. Clavibacter: A new genus containing some phytopathogenic coryneform bacteria, including Clavibacter xyli subsp. xyli sp. nov., subsp. nov. and Clavibacter xyli subsp. cynodontis subsp. nov., pathogens that cause ratoon stunting disease of sugarcane and bermudagrass stunting disease. Int. J. Syst. Evol. Microbiol. 1984, 34, 107-117.

9. Stackebrandt, E.; Rainey, F.A.; Ward-Rainey, N.L. Proposal for a new hierarchic classification system, Actinobacteria classis nov. Int. J. Syst. Evol. Microbiol. 1997, 47, 479-491. [CrossRef]

10. Gartemann, K.; Abt, B.; Bekel, T.; Burger, A.; Engemann, J.; Flügel, M.; Gaigalat, L.; Goesmann, A.; Gräfen, I.; Kalinowski, J. The genome sequence of the tomato-pathogenic actinomycete Clavibacter michiganensis subsp. michiganensis NCPPB382 reveals a large island involved in pathogenicity. J. Bacteriol. 2008, 190, 2138-2149. [CrossRef]

11. Nandi, M.; Macdonald, J.; Liu, P.; Weselowski, B.; Yuan, Z. Clavibacter michiganensis ssp. michiganensis: Bacterial canker of tomato, molecular interactions and disease management. Mol. Plant Pathol. 2018, 19, 2036-2050. [CrossRef]

12. Cantarel, B.L.; Coutinho, P.M.; Rancurel, C.; Bernard, T.; Lombard, V.; Henrissat, B. The Carbohydrate-Active EnZymes database (CAZy): An expert resource for glycogenomics. Nucleic Acids Res. 2009, 37, D233-D238. [CrossRef] [PubMed]

13. Balaji, V.; Mayrose, M.; Sherf, O.; Jacob-Hirsch, J.; Eichenlaub, R.; Iraki, N.; Manulis-Sasson, S.; Rechavi, G.; Barash, I.; Sessa, G. Tomato transcriptional changes in response to Clavibacter michiganensis subsp. michiganensis reveal a role for ethylene in disease development. Plant Physiol. 2008, 146, 1797-1809. [CrossRef] [PubMed]

14. Nürnberger, T.; Brunner, F.; Kemmerling, B.; Piater, L. Innate immunity in plants and animals: Striking similarities and obvious differences. Immunol. Rev. 2004, 198, 249-266. [CrossRef] [PubMed]

15. Zipfel, C.; Felix, G. Plants and animals: A different taste for microbes? Curr. Opin. Plant Biol. 2005, 8, 353-360. [CrossRef] [PubMed]

16. Asai, T.; Tena, G.; Plotnikova, J.; Willmann, M.R.; Chiu, W.; Gomez-Gomez, L.; Boller, T.; Ausubel, F.M.; Sheen, J. MAP kinase signalling cascade in Arabidopsis innate immunity. Nature 2002, 415, 977-983. [CrossRef] [PubMed]

17. van Loon, L.C.; Rep, M.; Pieterse, C.M. Significance of inducible defense-related proteins in infected plants. Annu. Rev. Phytopathol. 2006, 44, 135-162. [CrossRef] [PubMed]

18. Pieterse, C.M.; Leon-Reyes, A.; Van der Ent, S.; Van Wees, S.C. Networking by small-molecule hormones in plant immunity. Nat. Chem. Biol. 2009, 5, 308-316. [CrossRef] [PubMed]

19. Durrant, W.E.; Dong, X. Systemic acquired resistance. Annu. Rev. Phytopathol. 2004, 42, 185-209. [CrossRef] [PubMed]

20. Pieterse, C.M.; Van Wees, S.C.; Hoffland, E.; Van Pelt, J.A.; Van Loon, L.C. Systemic resistance in Arabidopsis induced by biocontrol bacteria is independent of salicylic acid accumulation and pathogenesis-related gene expression. Plant Cell. 1996, 8, 1225-1237. [PubMed]

21. Pieterse, C.M.; Van Wees, S.C.; Van Pelt, J.A.; Knoester, M.; Laan, R.; Gerrits, H.; Weisbeek, P.J.; Van Loon, L.C. A novel signaling pathway controlling induced systemic resistance in Arabidopsis. Plant Cell. 1998, 10, 1571-1580. [CrossRef] [PubMed] 
22. Pozo, M.J.; Van Der Ent, S.; Van Loon, L.C.; Pieterse, C.M. Transcription factor MYC2 is involved in priming for enhanced defense during rhizobacteria-induced systemic resistance in Arabidopsis thaliana. New Phytol. 2008, 180, 511-523. [CrossRef] [PubMed]

23. Werner, N.A.; Fulbright, D.W.; Podolsky, R.; Bell, J.; Hausbeck, M.K. Limiting populations and spread of Clavibacter michiganensis subsp. michiganensis on seedling tomatoes in the greenhouse. Plant Dis. 2002, 86, 535-542. [CrossRef] [PubMed]

24. de León, L.; Siverio, F.; López, M.M.; Rodríquez, A. Comparative efficiency of chemical compounds for in vitro and in vivo activity against Clavibacter michiganensis subsp. Michiganensis, the causal agent of tomato bacterial canker. Crop Prot. 2008, 27, 1277-1283. [CrossRef]

25. Carvalho, F.P. Agriculture, pesticides, food security and food safety. Environ. Sci. Policy. 2006, 9, 685-692. [CrossRef]

26. Damalas, C.A.; Eleftherohorinos, I.G. Pesticide exposure, safety issues, and risk assessment indicators. Int. J. Environ. Res. Public Health. 2011, 8, 1402-1419. [CrossRef] [PubMed]

27. Barratt, B.; Howarth, F.G.; Withers, T.M.; Kean, J.M.; Ridley, G.S. Progress in risk assessment for classical biological control. Biol. Control 2010, 52, 245-254. [CrossRef]

28. Gay, H. Before and after Silent Spring: From chemical pesticides to biological control and integrated pest management-Britain, 1945-1980. Ambix 2012, 59, 88-108. [CrossRef] [PubMed]

29. Amkraz, N.; Boudyach, E.H.; Boubaker, H.; Bouizgarne, B.; Aoumar, A.A.B. Screening for fluorescent pseudomonades, isolated from the rhizosphere of tomato, for antagonistic activity toward Clavibacter michiganensis subsp. michiganensis. World J. Microbiol. Biotechnol. 2010, 26, 1059-1065. [CrossRef]

30. Abo-Elyousr, K.A.; Bagy, H.M.K.; Hashem, M.; Alamri, S.A.; Mostafa, Y.S. Biological control of the tomato wilt caused by Clavibacter michiganensis subsp. michiganensis using formulated plant growth-promoting bacteria. Egypt J. Bio.l Pest Control 2019, 29, 54. [CrossRef]

31. Shin, D.J.; Yoo, S.-J.; Hong, J.K.; Weon, H.; Song, J.; Sang, M.K. Effect of Bacillus aryabhattai H26-2 and B. siamensis H30-3 on growth promotion and alleviation of heat and drought stresses in Chinese cabbage. Plant Pathol. J. 2019, 35, 178. [CrossRef] [PubMed]

32. Marefat, A.; Ophel-Keller, K.; McKay, A. A real-time PCR assay for detection of Clavibacter michiganensis subsp. insidiosus in lucerne. Australas. Plant Pathol. 2007, 36, 262-269. [CrossRef]

33. Baysal, Ö.; Gürsoy, Y.Z.; Örnek, H.; Duru, A. Induction of oxidants in tomato leaves treated with DL- $\beta$-Amino butyric acid (BABA) and infected with Clavibacter michiganensis ssp. michiganensis. Eur. J. Plant Pathol. 2005, 112, 361-369. [CrossRef]

34. Hwang, I.S.; Oh, E.; Lee, H.B.; Oh, C. Functional characterization of two cellulase genes in the Gram-positive pathogenic bacterium Clavibacter michiganensis for wilting in tomato. Mol. Plant-Microbe Interact. 2019, 32, 491-501. [CrossRef] [PubMed]

35. Kwak, A.M.; Min, K.J.; Lee, S.Y.; Kang, H.W. Water extract from spent mushroom substrate of Hericium erinaceus suppresses bacterial wilt disease of tomato. Mycobiology 2015, 43, 311-318. [CrossRef] [PubMed]

36. Mohd Nadzir, M.M.; Vieira Lelis, F.M.; Thapa, B.; Ali, A.; Visser, R.; van Heusden, A.W.; van der Wolf, J.M. Development of an in vitro protocol to screen Clavibacter michiganensis subsp. michiganensis pathogenicity in different Solanum species. Plant Pathol. 2019, 68, 42-48. [CrossRef]

37. Ftayeh, R.M.; von Tiedemann, A.; Rudolph, K.W. A new selective medium for isolation of Clavibacter michiganensis subsp. michiganensis from tomato plants and seed. Phytopathology 2011, 101, 1355-1364. [CrossRef]

38. Bradford, M.M. A rapid and sensitive method for the quantitation of microgram quantities of protein utilizing the principle of protein-dye binding. Anal. Biochem. 1976, 72, 248-254. [CrossRef]

39. Chalupowicz, L.; Cohen-Kandli, M.; Dror, O.; Eichenlaub, R.; Gartemann, K.; Sessa, G.; Barash, I.; Manulis-Sasson, S. Sequential expression of bacterial virulence and plant defense genes during infection of tomato with Clavibacter michiganensis subsp. michiganensis. Phytopathology 2010, 100, 252-261. [CrossRef]

40. Takishita, Y.; Charron, J.; Smith, D.L. Biocontrol rhizobacterium Pseudomonas sp. $23 S$ induces systemic resistance in tomato (Solanum lycopersicum L.) against bacterial canker Clavibacter michiganensis subsp. michiganensis. Front Microbiol. 2018, 9, 2119. [CrossRef]

41. Schnürer, J.; Rosswall, T. Fluorescein diacetate hydrolysis as a measure of total microbial activity in soil and litter. Appl. Environ. Microbiol. 1982, 43, 1256-1261. [CrossRef]

42. Kandeler, E.; Gerber, H. Short-term assay of soil urease activity using colorimetric determination of ammonium. Biol. Fertility Soils 1988, 6, 68-72. [CrossRef]

43. Tabatabai, M.A.; Bremner, J.M. Use of p-nitrophenyl phosphate for assay of soil phosphatase activity. Soil Biol. Biochem. 1969, 1, 301-307. [CrossRef]

44. Xu, W.; Ge, Z.; Poudel, D.R. Application and optimization of biolog ecoplates in functional diversity studies of soil microbial communities. MATEC Web Conf. 2015, 22, 04015. [CrossRef]

45. Shaner, G.; Finney, R.E. The effect of nitrogen fertilization on the expression of slow-mildewing resistance in Knox wheat. Phytopathology 1977, 67, 1051-1056. [CrossRef]

46. Hu, J.; Qian, W.; He, C. The Xanthomonas oryzae pv. oryzae eglXoB endoglucanase gene is required for virulence to rice. FEMS Microbiol. Lett. 2007, 269, 273-279. [CrossRef] [PubMed]

47. Stork, I.; GARTEMANN, K.; Burger, A.; Eichenlaub, R. A family of serine proteases of Clavibacter michiganensis subsp. michiganensis: chpC plays a role in colonization of the host plant tomato. Mol. Plant Pathol. 2008, 9, 599-608. [CrossRef] [PubMed] 
48. Baysal, Ö.; Soylu, E.M.; Soylu, S. Induction of defence-related enzymes and resistance by the plant activator acibenzolar-S-methyl in tomato seedlings against bacterial canker caused by Clavibacter michiganensis ssp. michiganensis. Plant Pathol. 2003, 52, 747-753. [CrossRef]

49. Soylu, S.; Baysal, Ö.; Soylu, E.M. Induction of disease resistance by the plant activator, acibenzolar-S-methyl (ASM), against bacterial canker (Clavibacter michiganensis subsp. michiganensis) in tomato seedlings. Plant Sci. 2003, 165, 1069-1075. [CrossRef]

50. Nicholson, R.L.; Hammerschmidt, R. Phenolic compounds and their role in disease resistance. Annu. Rev. Phytopathol. 1992, 30, 369-389. [CrossRef]

51. López-Ráez, J.A.; Verhage, A.; Fernández, I.; García, J.M.; Azcón-Aguilar, C.; Flors, V.; Pozo, M.J. Hormonal and transcriptional profiles highlight common and differential host responses to arbuscular mycorrhizal fungi and the regulation of the oxylipin pathway. J. Exp. Bot. 2010, 61, 2589-2601. [CrossRef]

52. Martínez-Medina, A.; Fernández, I.; Sánchez-Guzmán, M.J.; Jung, S.C.; Pascual, J.A.; Pozo, M.J. Deciphering the hormonal signalling network behind the systemic resistance induced by Trichoderma harzianum in tomato. Front. Plant Sci. $2013,4,206$. [CrossRef] [PubMed]

53. Savidor, A.; Teper, D.; Gartemann, K.; Eichenlaub, R.; Chalupowicz, L.; Manulis-Sasson, S.; Barash, I.; Tews, H.; Mayer, K.; Giannone, R.J. The Clavibacter michiganensis subsp. michiganensis-tomato interactome reveals the perception of pathogen by the host and suggests mechanisms of infection. J. Proteome Res. 2012, 11, 736-750. [CrossRef] [PubMed]

54. Goswami, D.; Patel, K.; Parmar, S.; Vaghela, H.; Muley, N.; Dhandhukia, P.; Thakker, J.N. Elucidating multifaceted urease producing marine Pseudomonas aeruginosa BG as a cogent PGPR and bio-control agent. Plant Growth Regul. 2015, 75, 253-263. [CrossRef] 